\title{
Effect of Oxide Additions on the Polymorphism of Tantalum Pentoxide
}

\section{III. "Stabilization" of the Low Temperature Structure Type}

\author{
R. S. Roth and J. L. Waring \\ Institute for Materials Research, National Bureau of Standards, \\ Washington, D.C. 20234
}

(March 11, 1970)

\begin{abstract}
The "low temperature structure type" of $\mathrm{Ta}_{2} \mathrm{O}_{5}$ has been found to occur in two distinct forms with the lowest temperature form having a unit cell 14 times the subcell and an intermediaie temperature form with a unit cell 11 times the subcell. The two types form intermediate partially ordered mixtures which are apparently in thermal equilibrium at various temperatures between $\sim 1000$ and $1350^{\circ} \mathrm{C}$. The addition of $\mathrm{MoO}_{3}, \mathrm{WO}_{3}, \mathrm{SiO}_{2}, \mathrm{GeO}_{2}, \mathrm{ZrO}_{2}, \mathrm{TiO}_{2}, \mathrm{~B}_{2} \mathrm{O}_{3}$ and $\mathrm{Al}_{2} \mathrm{O}_{3}$ each affect the multiplicity of the true unit cell in different ways. $\mathrm{WO}_{3}, \mathrm{SiO}_{2}, \mathrm{GeO}_{2}, \mathrm{~B}_{2} \mathrm{O}_{3}$, and $\mathrm{Al}_{2} \mathrm{O}_{3}$ form phases structurally similar to "low- $\mathrm{Ta}_{2} \mathrm{O}_{5}$ " which are stable up to the solidus temperatures of the corresponding systems.
\end{abstract}

Key words: Low temperature polymorph; single crystals; stabilization; tantalum oxide.

\section{Introduction}

The low-temperature form of $\mathrm{Ta}_{2} \mathrm{O}_{5}$ has an, as yet, unknown structure related to the low-temperature form of $\mathrm{Nb}_{2} \mathrm{O}_{5}$ as well as to $\alpha-U_{3} \mathrm{O}_{8}$ and $\alpha-U \mathrm{O}_{3}$. As $\mathrm{Ta}_{2} \mathrm{O}_{5}$ exhibits a reversible phase transition at about $1360^{\circ} \mathrm{C}$ to a structurally dissimilar high-temperature form $[1]^{1}$ it is not possible to grow single crystals of the room temperature stable form by conventional high-temperature techniques such as the Verneuil and the Czochralski methods. Whereas impurities appear to enter into solid solution in the high-temperature form of $\mathrm{Ta}_{2} \mathrm{O}_{5}$ [2] they apparently form new discrete phases in the low-temperature form [2]. In a previous publication [2] the present authors suggested that at least two discrete phases related to the low temperature form of $\mathrm{Ta}_{2} \mathrm{O}_{5}\left(\mathrm{~L}^{-} \mathrm{Ta}_{2} \mathrm{O}_{5}\right)$ were formed at about 2 and 12.5 mol percent $\mathrm{TiO}_{2}$ in the $\mathrm{Ta}_{2} \mathrm{O}_{5}: \mathrm{TiO}_{2}$ system. However, these phases transform at even lower temperatures than does the low-temperature form of pure $\mathrm{Ta}_{2} \mathrm{O}_{5}$. Jahnberg and Andersson [3] concluded that a series of discrete compounds of a similar type exist in the system $\mathrm{Ta}_{2} \mathrm{O}_{5}-\mathrm{TaO}_{2} \mathrm{~F}$. Although they were able to obtain small crystals by heating specimens in sealed Pt tubes between 800 and $1300{ }^{\circ} \mathrm{C}$ they did not report any crystallographic or phase equilibria data for these phases.

\footnotetext{
${ }^{1}$ Figures in brackets indicate the literature references at the end of this paper.
}

In the present study, oxides containing cations smaller than $\mathrm{Ta}^{+5}$ have been added to $\mathrm{Ta}_{2} \mathrm{O}_{5}$ in an effort to obtain compounds related to $\mathrm{L}-\mathrm{Ta}_{2} \mathrm{O}_{5}$ which may be stable at the melting point of the compositions.

\section{Materials, Specimen Preparation, and Test Methods}

The general quantitative spectrochemical analyses for the $\mathrm{Ta}_{2} \mathrm{O}_{5}$ used in this study has been previously reported [2]. All other oxides used were of reagent grade or better as described in previous publications [4]. These other oxides were $\mathrm{MoO}_{3}, \mathrm{WO}_{3}, \mathrm{SiO}_{2}$, $\mathrm{GeO}_{2}, \mathrm{~B}_{2} \mathrm{O}_{3}$, and $\mathrm{Al}_{2} \mathrm{O}_{3}$. Some of the results previously reported for $\mathrm{ZrO}_{2}$ [5] are duplicated here for discussion. The specimen preparation and test methods were the same as reported in the previous paper [5].

\section{Results and Discussion}

The experimental data is shown in table 1 and interpreted diagramatically as phase equilibria data in figures 1-3. The table columns need no comment except for the next to last and last columns. The "C-line" represents the position of a characteristic and diagnostic peak in the $\mathrm{x}$-ray powder diffraction patterns, first referred to by Moser [6].

Moser has pointed out that the exact nature of the $\mathrm{x}$-ray diffraction powder pattern of low- $\mathrm{Ta}_{2} \mathrm{O}_{5}$ is dependent upon the heat treatment of the specimen. 
On the basis of the position of one characteristic peak (called the " $\mathrm{C}$ " line) he divided low- $\mathrm{Ta}_{2} \mathrm{O}_{5}$ into four different conditions ("Zustanden") with the notation that one grades into the other with no perceptible boundaries. This " $\mathrm{C}$ "-line was also found in the present study to be very diagnostic of the amount of impurities added to $\mathrm{Ta}_{2} \mathrm{O}_{5}$, and its position is listed in table 1 for each specimen in which it could be observed.
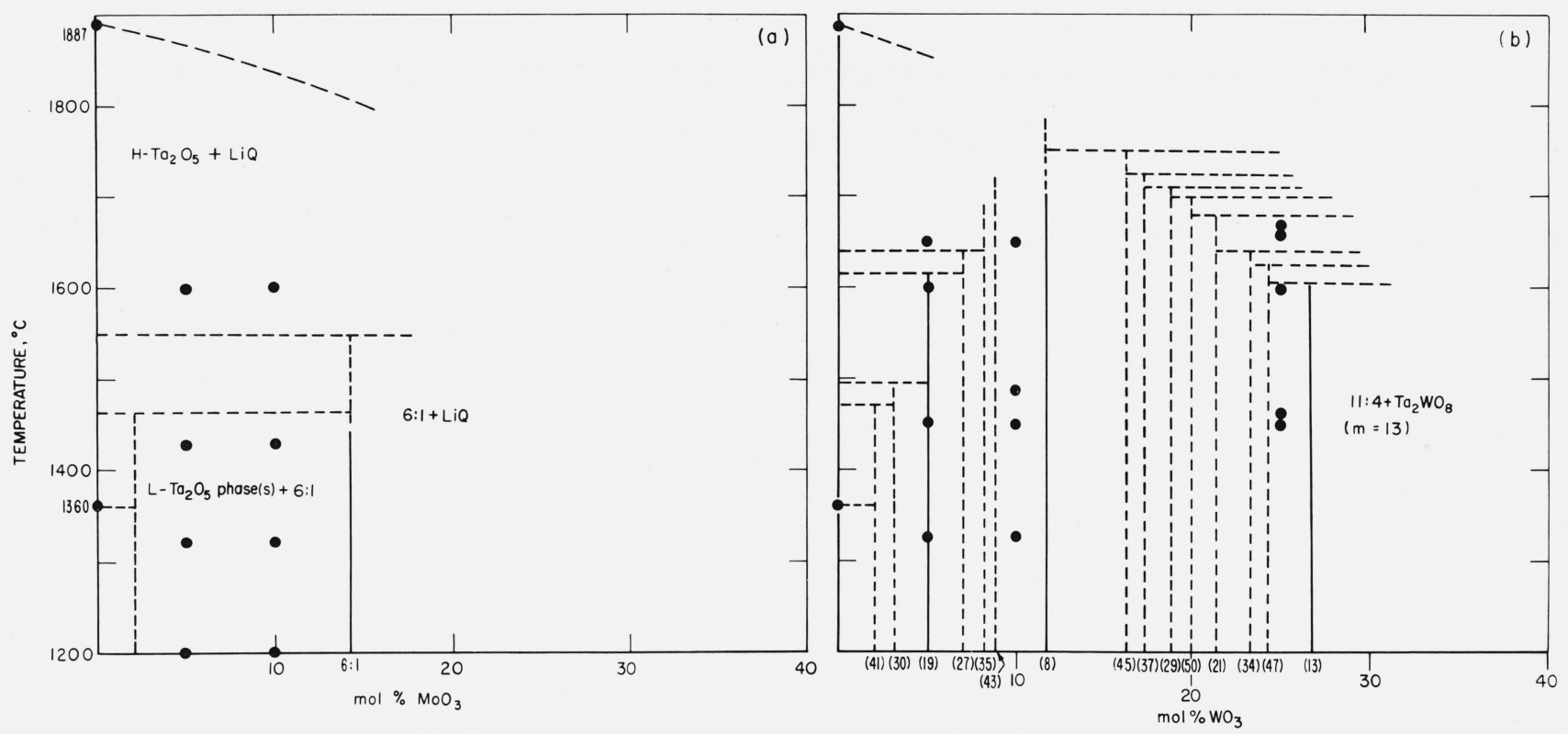

FIGURE 1. $\mathrm{Ta}_{2} \mathrm{O}_{5}$-rich regions of $\mathrm{Ta}_{2} \mathrm{O}_{5}-\mathrm{MeO}_{3}$ systems, as deduced from limited quenching and $x$-ray diffraction data.

- experimental data points

$\mathrm{H}-\mathrm{Ta}_{2} \mathrm{O}_{5}$ - high temperature form of $\mathrm{Ta}_{2} \mathrm{O}_{5}$

$\mathrm{L}-\mathrm{Ta}_{2} \mathrm{O}_{5}$ phase(s) - one or more phases with an x-ray powder diffraction pattern similar to the low temper ure form of $\mathrm{Ta}_{2} \mathrm{O}$

( ) - numbers in parentheses indicate postulated multiplicity $(m)$ of the unit cell for the indicated compositions. 

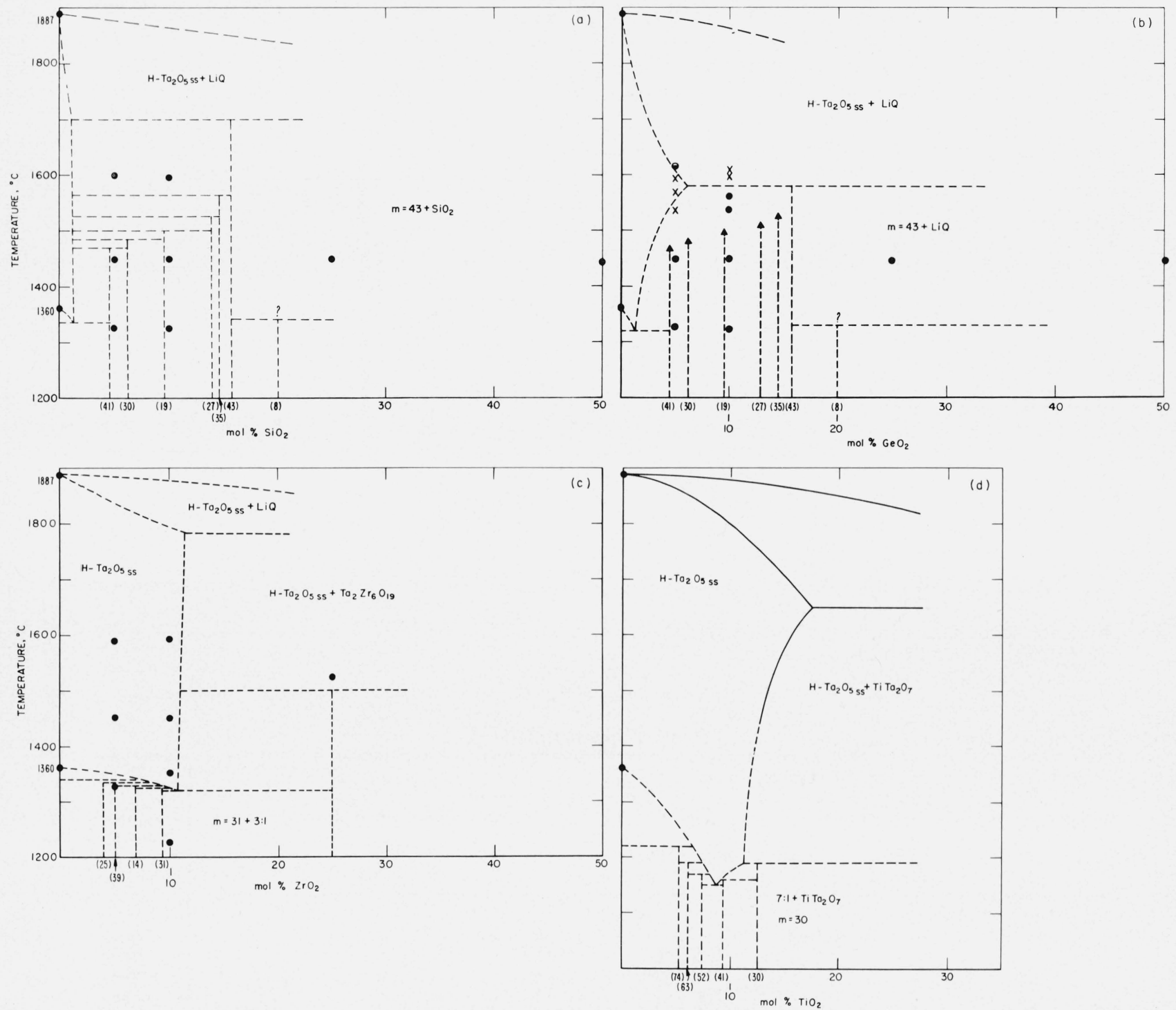

FIGURE 2. $\mathrm{Ta}_{2} \mathrm{O}_{5}$-rich regions of $\mathrm{Ta}_{2} \mathrm{O}_{5}-\mathrm{MeO}_{2}$ systems, as deduced from limited quenching and x-ray diffraction data.

- experimental data points

X-experimental data point - composition may have changed due to leak or reaction with $\mathrm{Pt}$ tube

$\mathrm{H}-\mathrm{Ta}_{2} \mathrm{O}_{5}$ - high temperature form of $\mathrm{Ta}_{2} \mathrm{O}_{5}$

ss - solid solution. 

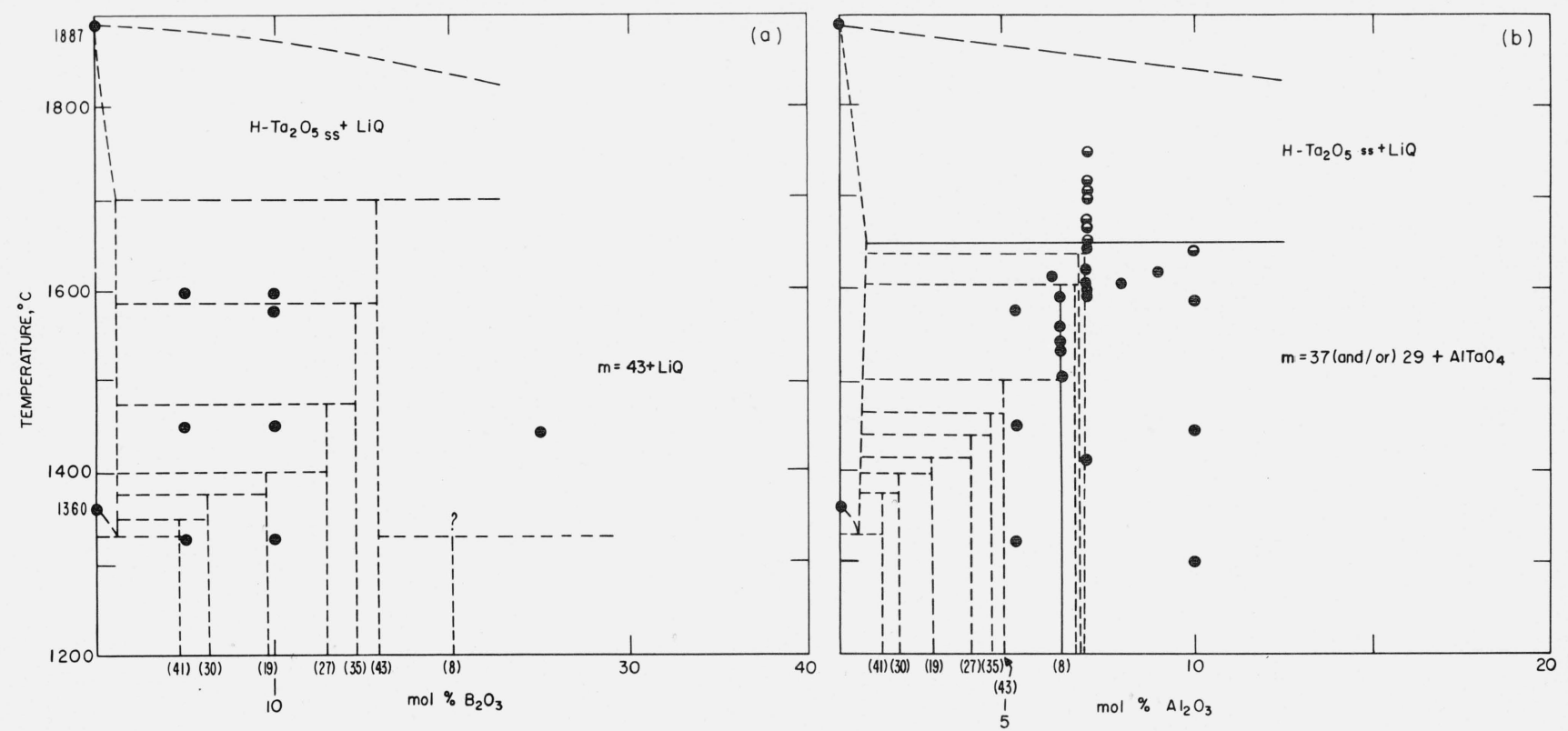

FIGURE 3. $\mathrm{Ta}_{2} \mathrm{O}_{5}$-rich regions of $\mathrm{Ta}_{2} \mathrm{O}_{5}-\mathrm{Me}_{2} \mathrm{O}_{3}$ systems, as deduced from limited quenching and $x$-ray diffraction data.

- experimental data points.

H-Ta ${ }_{2} \mathrm{O}_{5}-$ high temperature form of $\mathrm{Ta}_{2} \mathrm{O}_{5}$

ss - solid solution.

TABLE 1. Experimental data

\begin{tabular}{|c|c|c|c|c|c|c|c|c|}
\hline \multirow{3}{*}{ System } & \multirow{3}{*}{$\begin{array}{l}\text { Composi- } \\
\text { tion }\end{array}$} & \multicolumn{4}{|c|}{ Heat treatment } & \multirow{3}{*}{ X-ray diffraction analyses ${ }^{c}$} & \multirow{3}{*}{$\begin{array}{l}\text { "C" line } \mathrm{CuK} \alpha \\
\text { radiation } 2 \theta_{\mathrm{obs}}\end{array}$} & \multirow{3}{*}{$m$} \\
\hline & & \multicolumn{2}{|c|}{ Initial $^{a}$} & \multicolumn{2}{|c|}{ Final $^{b}$} & & & \\
\hline & & $\underset{{ }^{\circ} \mathrm{C}}{\text { Temp. }}$ & $\underset{\mathrm{hr}}{\mathrm{Time}}$ & $\underset{{ }^{\circ} \mathrm{C}}{\text { Temp. }}$ & $\underset{\mathrm{hr}}{\mathrm{Time}}$ & & & \\
\hline $\mathrm{Ta}_{2} \mathrm{O}_{5}-\mathrm{MoO}_{3}$ & $95: 5$ & $\begin{array}{r}e^{e} 1702 \\
1350 \\
\\
{ }^{e} 1405 \\
\\
500 \\
f 700 \\
f_{f} 1200\end{array}$ & $\begin{array}{l}2.5 \\
10 \\
60 \\
60\end{array}$ & $\begin{array}{r}{ }^{d} 995 \\
1220 \\
{ }^{d} 1326 \\
{ }^{d} 1327 \\
{ }^{d} 1389 \\
{ }^{d} 1402 \\
{ }^{d} 1402 \\
{ }^{d} 1448 \\
{ }^{d} 1448 \\
{ }^{d} 1450 \\
{ }^{d} 1450 \\
{ }^{d} 1498 \\
{ }^{d} 1499 \\
{ }^{d} 1224 \\
1225 \\
{ }^{d} 1402 \\
{ }^{d} 1404 \\
{ }^{d} 1499 \\
\\
{ }^{d} 995 \\
{ }^{d} 1162 \\
\\
1185 \\
1323 \\
1426 \\
1599\end{array}$ & $\begin{array}{c}552 \\
264 \\
24 \\
312 \\
1.0 \\
2.0 \\
17 \\
2 \\
1 \\
0.5 \\
.25 \\
.08 \\
.03 \\
\\
425 \\
353 \\
\\
1.0 \\
5.0 \\
0.03 \\
\\
552 \\
168 \\
\\
19 \\
71 \\
19 \\
4.5\end{array}$ & 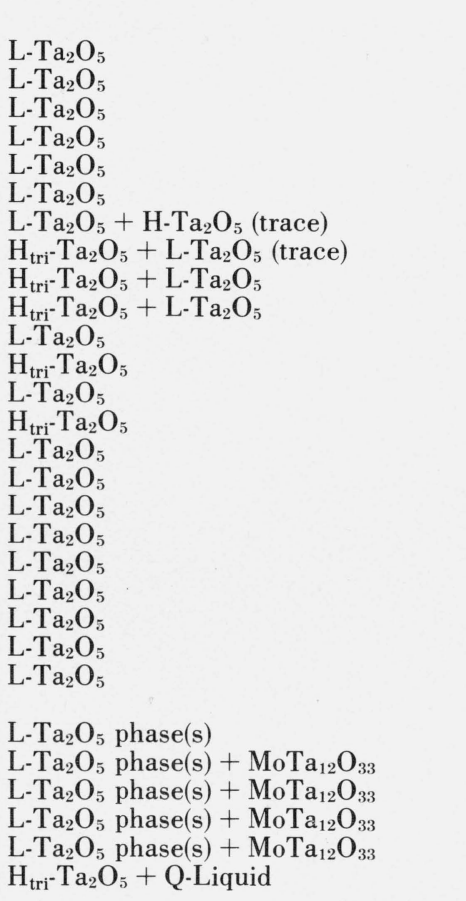 & $\begin{array}{l}26.38 \\
\\
26.37 \\
26.40 \\
26.44 \\
26.55 \\
26.45 \\
26.43 \\
26.35 \\
26.38 \\
26.65 \\
26.58\end{array}$ & 14 \\
\hline
\end{tabular}


TABLE 1. Experimental data-Continued

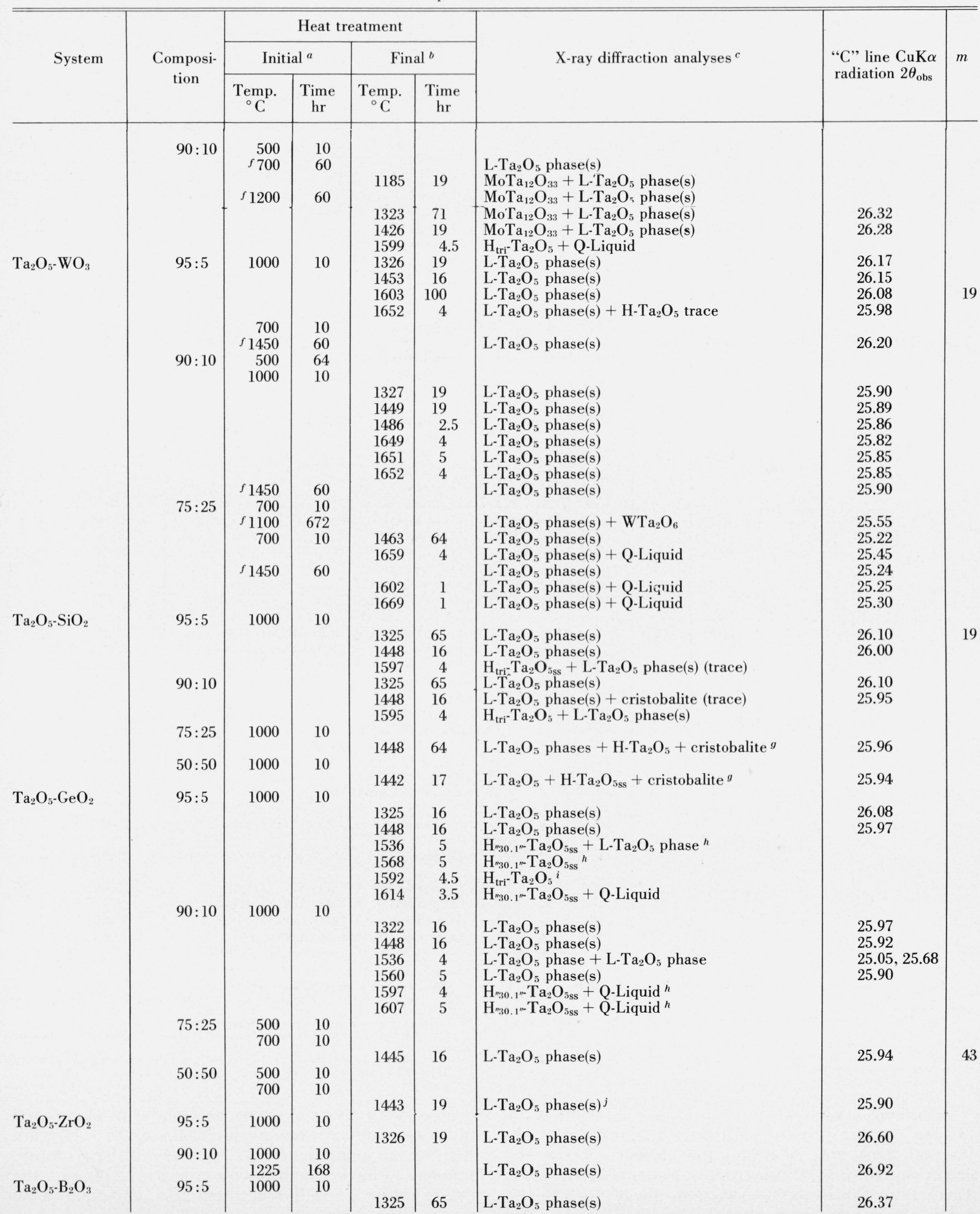


TABLE 1. Experimental data-Continued

\begin{tabular}{|c|c|c|c|c|c|c|c|c|}
\hline \multirow{3}{*}{ System } & \multirow{3}{*}{$\begin{array}{l}\text { Composi- } \\
\text { tion }\end{array}$} & \multicolumn{4}{|c|}{ Heat treatment } & \multirow{3}{*}{ X-ray diffraction analyses ${ }^{c}$} & \multirow{3}{*}{$\begin{array}{l}\text { "C" line } \mathrm{CuK} \alpha \\
\text { radiation } 2 \theta_{\mathrm{obs}}\end{array}$} & \multirow{3}{*}{$m$} \\
\hline & & \multicolumn{2}{|c|}{ Initial $^{a}$} & \multicolumn{2}{|c|}{ Final $^{b}$} & & & \\
\hline & & $\underset{{ }^{\circ} \mathrm{C}}{\mathrm{Temp}}$ & $\underset{\mathrm{hr}}{\operatorname{Time}}$ & $\underset{{ }^{\circ} \mathrm{C}}{\text { Temp. }}$ & $\underset{\mathrm{hr}}{\operatorname{Time}}$ & & & \\
\hline $\mathrm{Ta}_{2} \mathrm{O}_{5}-\mathrm{Al}_{2} \mathrm{O}_{3}$ & $\begin{array}{l}90: 10 \\
75: 25 \\
95: 5 \\
94: 6 \\
93: 7\end{array}$ & $\begin{array}{l}1200 \\
1560 \\
1600\end{array}$ & $\begin{array}{r}6 \\
60 \\
12\end{array}$ & $\begin{array}{l}1449 \\
1596 \\
1326 \\
1449 \\
1576 \\
1595 \\
\\
1442 \\
1322 \\
1449 \\
1576 \\
1611 \\
\\
1504 \\
1534 \\
1540 \\
1558 \\
1592 \\
1594 \\
1598 \\
1668 \\
1674 \\
\end{array}$ & $\begin{array}{c}16 \\
4.5 \\
16 \\
16 \\
5.5 \\
4 \\
\\
\\
20 \\
\\
65 \\
16 \\
5.5 \\
4 \\
4 \\
\\
20 \\
336 \\
20 \\
139 \\
142 \\
288 \\
4 \\
4 \\
16 \\
\\
\\
20 \\
3.5 \\
4 \\
4 \\
4 \\
1 \\
1 \\
1 \\
1 \\
4 \\
\\
4 \\
16 \\
64 \\
4 \\
4 \\
\end{array}$ & 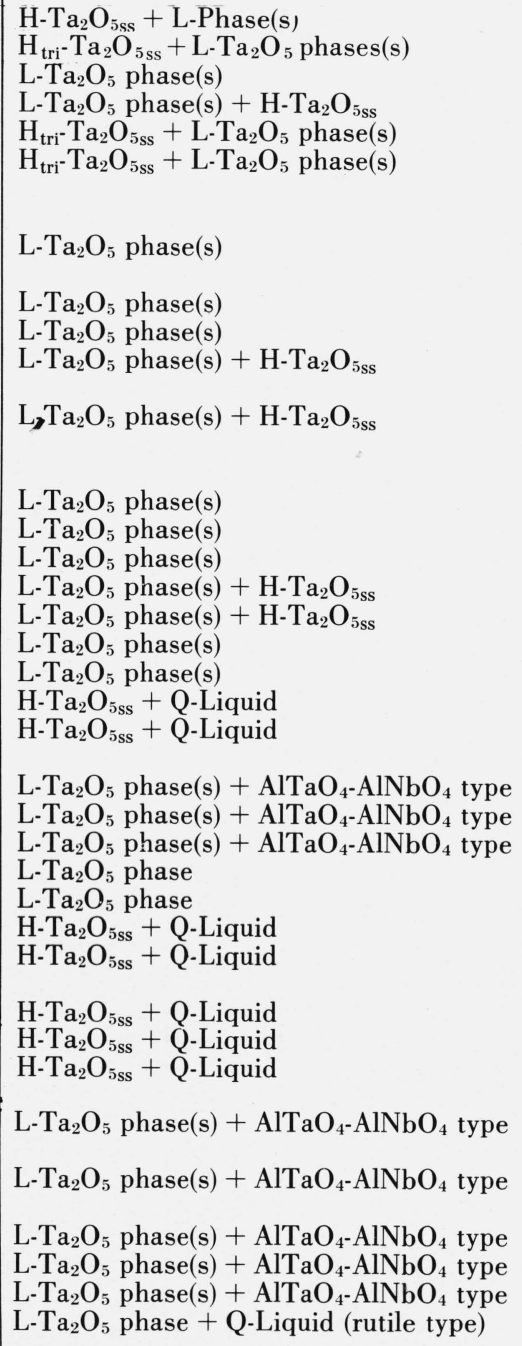 & $\begin{array}{l}25.85 \\
25.84 \\
25.76 \\
25.63 \\
\\
25.63 \\
\\
\\
25.65 \\
25.65 \\
25.65 \\
25.65 \\
25.65 \\
25.63 \\
25.60\end{array}$ & 43 \\
\hline
\end{tabular}

a Initial Heat Treatment-All specimens were calcined as pressed disks on $\mathrm{Pt}$ foil at the indicated heat treatment with heating and cooling rates of approximately $4 .{ }^{\circ} \mathrm{C} / \mathrm{min}$, unless otherwise specified.

$\underset{b}{b}$ Final Heat Treatment-All specimens were quenched in sealed Pt tubes from the indicated temperature (unless otherwise specified).

$c$ The phases identified are given in order of amount present at room temperature (greatest amount first). The phases are not necessarily those present at the temperature to which the specimen was heated.

Pt tube not sealed.

Examination of single crystals [7] has shown that the "C-line" of the powder pattern is actually a $1 \mathrm{k} 0$ diffraction peak and is always the closest spot on the origin side of the $1 \mathrm{k} 0$ substructure reflection. The Low$\mathrm{Ta}_{2} \mathrm{O}_{5}$ type phases in these systems always have only a $b$ axis superstructure so that the "C-line" can be used directly to calculate the true unit cell. All of the super- e Quenched from indicated temperature.

$f$ Specimen was sealed in a large $\mathrm{Pt}$ tube to minimize possible loss of more volatile component.

$g$ Presence of three phases indicates non-equilibrium.

Pt tube.

Probably due to change of specimen composition by the addition oxide reacting with

$i$ Specimen tube leaked and all or most of addition oxide was lost by volatilization.

$j$ Petrographic examination shows considerable amounts of glass.

structures in these systems are made up of ordered mixtures of phases having multiples of $3 n+5$ (multiplicities, $m$ ) along the $b$ axis [7]. Thus, if the structure happens to have a multiplicity of $5,8,11,14$, etc., the strong substructure line at about $28.3^{\circ} 2 \theta(\mathrm{CuK} \alpha$ radiation) will have the index (150), $(180),(1,11,0),(1,14,0)$, etc., and the "C-line" will be $(140),(170),(1,10,0)$, 
$(1,13,0)$, etc. If, however, the true structure is a mixture of $3 n+5$ multiplicities such as

$$
5+8=13 \text { or } \quad 5+8+8=21,
$$

etc., the substructure line will be $(1,13,0),(1,21,0)$, etc., and the "C-line" will be $(1,11,0),(1,18,0)$, etc. The "C-line," therefore, has a $k$ index equal to $(m-x)$ where $m$ equals the multiplicity and $x$ equals the number of $(3 n+5)$ phases involved in the ordered mixture. For $m=5,13,8,19,11,25$, and 14 the "C-line" has been observed to equal $\left(24.14^{\circ}\right)^{2}, 25.18^{\circ}, 25.75^{\circ}, 26.08^{\circ}$, $26.38^{\circ}, 26.58^{\circ}$ and $26.76^{\circ}, 2 \theta(\mathrm{CuK} \alpha$ radiation), respectively. From the above information the real multiplicity and true unit cell (the $b$ axis) can be calculated by trial and error and the powder pattern completely and uniquely indexed on this basis. The calculated multiplicity $(m)$ is listed in table 1 for some of the appropriate specimens.

The Low Temperature Polymorph(s) of $\mathrm{Ta}_{2} \mathrm{O}_{5}$. The various "conditions" of the low temperature form of $\mathrm{Ta}_{2} \mathrm{O}_{5}$ reported by Moser [6] can now be explained in terms of the multiplicities of their unit cells, as shown by the C-line (see figs. 15 and 16 and table 14 of ref. [6]). Moser used several different methods of preparing $\mathrm{Ta}_{2} \mathrm{O}_{5}$ and on the basis of the value of the $\mathrm{C}$-line divided them into four different conditions: $\alpha_{1}, \alpha_{2}, \alpha_{3}$, and $\alpha_{4}$. His $\alpha_{2}$ phase corresponds approximately to a multiplicity of 8 times the subcell and grades into $\alpha_{1}$ which is about $8+13=21$. These specimens were mostly from transport reactions or heat treatments above the phase transition. It can be concluded from the present work that these materials have been contaminated by the transport medium or during the heat treatment and do not represent pure $\mathrm{Ta}_{2} \mathrm{O}_{5}$. The $\alpha_{4}$ phase apparently also is contaminated by impurities either from the transport reaction or from $\mathrm{OH}^{-}$present in the amorphous or semiamorphous starting materials. The quoted value of the C-line makes $\alpha_{4}$ intermediate in composition between the 8 and 11 multiplicities or about $m=19$.

The $\alpha_{3}$ phase of Moser therefore is probably the only condition which represents pure $\mathrm{Ta}_{2} \mathrm{O}_{5}$. This condition still is not very satisfactory as the C-line varies with temperature of heat treatment from about $26.75^{\circ} 2 \theta$ to $26.35^{\circ} 2 \theta$ (table 1). Furthermore, the position of the C-line versus temperature apparently represents an equilibrium condition as it can be made to occur at the same value when approached from higher temperatures as when approached from low temperatures. This condition is reversible (table 1 ).

The as-received materials from several different sources all contain a C-line at about $26.75^{\circ} 2 \theta$ and represents the largest value (smallest $d$ value) which can be observed for pure $\mathrm{Ta}_{2} \mathrm{O}_{5}$. This value corresponds approximately to a multiplicity of 14 times the subcell. Upon heating above $1000{ }^{\circ} \mathrm{C}$ the $\mathrm{C}$-line changes gradually with temperature to a value of $26.38^{\circ} 2 \theta$ at the phase transition temperature $\sim 1360{ }^{\circ} \mathrm{C}$. Unlike Moser's report, heating above this temperature did not cause a significant further shift in the value of the

\footnotetext{
${ }^{2}$ Calculated.
}

C-line. This last position corresponds to a multiplicity of about 11. Small single crystals of pure $\mathrm{Ta}_{2} \mathrm{O}_{5}$ with $m=11$ can be obtained by inverting the high temperature form and holding the specimen for many weeks just below the phase transition. These crystals have been used to study the crystal structure of low $\mathrm{Ta}_{2} \mathrm{O}_{5}$ $(m=11)$ and the results of this study have been reported elsewhere (Stephenson and Roth [8]).

It may be concluded therefore that pure $\mathrm{Ta}_{2} \mathrm{O}_{5}$ exists in two low temperature polymorphic types: the lowest temperature form $\left(\sim 1000{ }^{\circ} \mathrm{C}\right.$ and below $)$ with $m=14$ $\left(\mathrm{Ta}_{28} \mathrm{O}_{70}\right)$ and a higher temperature form $\left(\sim 1350{ }^{\circ} \mathrm{C}\right)$ with $m=11\left(\mathrm{Ta}_{22} \mathrm{O}_{55}\right)$. At intermediate temperatures ordered (or partially ordered) mixtures of the two phases occur in equilibrium with each other. The crystal structures of the two types must be very similar, and one can grade into the other by a small movement of only a few of the atoms (Stephenson and Roth [8]).

The Effect of other Ions on the Low Temperature Polymorph(s). It can be seen from table 1 and figures 1-3 that $\mathrm{WO}_{3}, \mathrm{SiO}_{2}, \mathrm{GeO}_{2}, \mathrm{~B}_{2} \mathrm{O}_{3}$, and $\mathrm{Al}_{2} \mathrm{O}_{3}$ when added to $\mathrm{Ta}_{2} \mathrm{O}_{5}$ all form phases structurally similar to low$\mathrm{Ta}_{2} \mathrm{O}_{5}$ which are stable up to the solidus temperatures of the corresponding systems. These oxides all contain small cations which are often found in tetrahedral coordination. It may be inferred that the stabilizing influence of these oxides on the $\mathrm{L}-\mathrm{Ta}_{2} \mathrm{O}_{5}$ structure-type is due to the cations entering into the structure interstitially in tetrahedral coordination, or else lowering the average cation radius by substituting for $\mathrm{Ta}^{+5}$ in the lattice. $\mathrm{MoO}_{3}$, although even more likely than $\mathrm{WO}_{3}$ to go into tetrahedral coordination does not form these stable phases at high temperatures. Instead a new compound isostructural with $\mathrm{WNb}_{12} \mathrm{O}_{33}$ is formed with the $\mathrm{Mo}^{+6}$ ion in tetrahedral coordination and all the $\mathrm{Ta}^{+5}$ ions in octahedral coordination. $\mathrm{GeO}_{2}$ apparently reacts with the Pt tubes when held at high temperatures for long periods of time (table 1), thus, making determination of the true equilibrium diagram very difficult. The $\mathrm{Ta}_{2} \mathrm{O}_{5}-\mathrm{B}_{2} \mathrm{O}_{3}$ and $\mathrm{Ta}_{2} \mathrm{O}_{5}-\mathrm{SiO}_{2}$ systems show some promise in terms of determining the true phase diagrams. However, the $\mathrm{Ta}_{2} \mathrm{O}_{5}-\mathrm{Al}_{2} \mathrm{O}_{3}$ and $\mathrm{Ta}_{2} \mathrm{O}_{5}-\mathrm{WO}_{3}$ systems appear to offer the most promise for determining the nature of the low- $\mathrm{Ta}_{2} \mathrm{O}_{5}$ type phases, as the characteristic "C"-line shows the most displacement for these systems.

The data for the system $\mathrm{Ta}_{2} \mathrm{O}_{5}-\mathrm{ZrO}_{2}$ is reproduced in table 1 (from ref. [5]) as this is the only system yet found in which the " $\mathrm{C}$ "-line is displaced (from pure $\mathrm{Ta}_{2} \mathrm{O}_{5}$ ) toward higher $2 \theta$ (smaller $d$ ). It can be assumed that $\mathrm{HfO}_{2}$ will also cause this type of displacement. These phases are not stable at high temperatures, since both $\mathrm{Zr}^{+4}$ and $\mathrm{Hf}^{+4}$ are larger than $\mathrm{Ta}^{+5}$ and would increase the average radius of the cations.

The exact compositions at which each multiplicity is postulated to occur in the systems studied is shown in tables $2 \mathrm{a}$ and $2 \mathrm{~b}$. The addition ion is believed to occur substitutionally in the $\mathrm{Ta}_{2} \mathrm{O}_{5}$ structure in the systems involving $\mathrm{WO}_{3}, \mathrm{TiO}_{2}, \mathrm{ZrO}_{2}$, and $\mathrm{Al}_{2} \mathrm{O}_{3}$ but interstitually, in tetrahedral coordination, for the systems involving $\mathrm{MoO}_{3}, \mathrm{SiO}_{2}, \mathrm{GeO}_{2}$, and $\mathrm{B}_{2} \mathrm{O}_{3}$. All values of 
TABLE 2a. Postulated compositions of phases in the systems involving $\mathrm{Ta}_{2} \mathrm{O}_{5}$ and oxides of other small cations

\begin{tabular}{|c|c|c|c|c|c|}
\hline $\begin{array}{l}\text { System } \\
\text { and } \\
\text { mol ratio }\end{array}$ & $m^{a}$ & $\begin{array}{c}x_{1}^{b} \\
(m=13)\end{array}$ & $\begin{array}{c}x_{2} \\
(m=8)\end{array}$ & $\begin{array}{c}x_{3} \\
(m=11)\end{array}$ & $\begin{array}{c}\text { Formula } \\
\text { per } \\
\text { unit cell }\end{array}$ \\
\hline $\mathrm{Ta}_{2} \mathrm{O}_{5}$ & 11 & & & 1 & $\mathrm{Ta}_{22} \mathrm{O}_{55}$ \\
\hline $\mathrm{Ta}_{2} \mathrm{O}_{5}: \mathrm{WO}_{3}$ & & $\left(\mathrm{Ta}_{22} \mathrm{~W}_{4} \mathrm{O}_{67}\right)$ & $\left(\mathrm{Ta}_{15} \mathrm{WO}_{40.5}\right)$ & $\left(\mathrm{Ta}_{22} \mathrm{O}_{55}\right)$ & \\
\hline $81: 2$ & 41 & & 1 & 3 & $\mathrm{Ta}_{81} \mathrm{WO}_{205.5}$ \\
\hline $59: 2$ & 30 & & 1 & 2 & $\mathrm{Ta}_{59} \mathrm{WO}_{150.5}$ \\
\hline $37: 2$ & 19 & & 1 & 1 & $\mathrm{Ta}_{37} \mathrm{WO}_{95.5}$ \\
\hline $13: 1$ & 27 & & 2 & 1 & $\mathrm{Ta}_{52} \mathrm{~W}_{2} \mathrm{O}_{136}$ \\
\hline $67: 6$ & 35 & & 3 & 1 & $\mathrm{Ta}_{67} \mathrm{~W}_{3} \mathrm{O}_{176.5}$ \\
\hline $41: 4$ & 43 & & 4 & 1 & $\mathrm{Ta}_{82} \mathrm{~W}_{4} \mathrm{O}_{217}$ \\
\hline $15: 2$ & 8 & & 1 & & $\mathrm{Ta}_{15} \mathrm{WO}_{40.5}$ \\
\hline $41: 8$ & 45 & $\dddot{1}$ & 4 & & $\mathrm{Ta}_{82} \mathrm{~W}_{8} \mathrm{O}_{229}$ \\
\hline $67: 14$ & 37 & 1 & 3 & & $\mathrm{Ta}_{67} \mathrm{~W}_{7} \mathrm{O}_{188.5}$ \\
\hline $13: 3$ & 29 & 1 & 2 & & $\mathrm{Ta}_{52} \mathrm{~W}_{6} \mathrm{O}_{148}$ \\
\hline $89: 22$ & 50 & 2 & 3 & & $\mathrm{Ta}_{89} \mathrm{~W}_{11} \mathrm{O}_{25}$ \\
\hline $37: 10$ & 21 & 1 & 1 & & $\mathrm{Ta}_{37} \mathrm{~W}_{5} \mathrm{O}_{107.5}$ \\
\hline $59: 18$ & 34 & 2 & 1 & & $\mathrm{Ta}_{59} \mathrm{~W}_{9} \mathrm{O}_{174.5}$ \\
\hline $81: 26$ & 47 & 3 & 1 & & $\mathrm{Ta}_{81} \mathrm{~W}_{13} \mathrm{O}_{241.5}$ \\
\hline $11: 4$ & 13 & 1 & & & $\mathrm{Ta}_{22} \mathrm{~W}_{4} \mathrm{O}_{67}$ \\
\hline $\mathrm{Ta}_{2} \mathrm{O}_{5}: \mathrm{SiO}_{2}$ & & & $\left(\mathrm{Si}_{2} \mathrm{Ta}_{16} \mathrm{O}_{44}\right)$ & $\left(\mathrm{T}_{22} \mathrm{O}_{55}\right)$ & \\
\hline $41: 2$ & 41 & & 1 & 3 & $\mathrm{Si}_{2} \mathrm{Ta}_{82} \mathrm{O}_{209}$ \\
\hline $15: 1$ & 30 & & 1 & 2 & $\mathrm{Si}_{2} \mathrm{Ta}_{60} \mathrm{O}_{154}$ \\
\hline $19: 2$ & 19 & & 1 & 1 & $\mathrm{Si}_{2} \mathrm{Ta}_{38} \mathrm{O}_{99}$ \\
\hline $27: 4$ & 27 & & 2 & 1 & $\mathrm{Si}_{4} \mathrm{Ta}_{54} \mathrm{O}_{143}$ \\
\hline $35: 6$ & 35 & & 3 & 1 & $\mathrm{Si}_{6} \mathrm{Ta}_{70} \mathrm{O}_{187}$ \\
\hline $43: 8$ & 43 & & 4 & 1 & $\mathrm{Si}_{8} \mathrm{Ta}_{86} \mathrm{O}_{231}$ \\
\hline $4: 1$ & 8 & & 1 & & $\mathrm{Si}_{2} \mathrm{Ta}_{16} \mathrm{O}_{44}$ \\
\hline $\mathrm{Ta}_{2} \mathrm{O}_{5}: \mathrm{TiO}_{2}$ & & & $\left(\mathrm{Ta}_{12} \mathrm{Ti}_{4} \mathrm{O}_{38}\right)$ & $\left(\mathrm{Ta}_{22} \mathrm{O}_{55}\right)$ & \\
\hline $18: 1$ & 74 & & 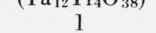 & 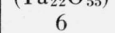 & $\mathrm{Ta}_{144} \mathrm{Ti}_{4} \mathrm{O}_{368}$ \\
\hline $61: 4$ & 63 & & 1 & 5 & $\mathrm{Ta}_{122} \mathrm{Ti}_{4} \mathrm{O}_{313}$ \\
\hline $25: 2$ & 52 & & 1 & 4 & $\mathrm{Ta}_{100} \mathrm{Ti}_{4} \mathrm{O}_{258}$ \\
\hline $39: 4$ & 41 & & 1 & 3 & $\mathrm{Ta}_{78} \mathrm{Ti}_{4} \mathrm{O}_{203}$ \\
\hline $7: 1$ & 30 & & 1 & 2 & $\mathrm{Ta}_{56} \mathrm{Ti}_{4} \mathrm{O}_{148}$ \\
\hline $\mathrm{Ta}_{2} \mathrm{O}_{5}: \mathrm{B}_{2} \mathrm{O}_{3}$ & & & $\left(\mathrm{~B}_{4} \mathrm{Ta}_{16} \mathrm{O}_{46}\right)$ & $\left(\mathrm{Ta}_{22} \mathrm{O}_{55}\right)$ & \\
\hline $41: 2$ & 41 & & 1 & 3 & $\mathrm{~B}_{4} \mathrm{Ta}_{82} \mathrm{O}_{211}$ \\
\hline $15: 1$ & 30 & & 1 & 2 & $\mathrm{~B}_{4} \mathrm{Ta}_{60} \mathrm{O}_{156}$ \\
\hline $19: 2$ & 19 & & 1 & 1 & $\mathrm{~B}_{4} \mathrm{Ta}_{38} \mathrm{O}_{101}$ \\
\hline $27: 4$ & 27 & & 2 & 1 & $\mathrm{~B}_{8} \mathrm{Ta}_{54} \mathrm{O}_{147}$ \\
\hline $35: 6$ & 35 & & 3 & 1 & $\mathrm{~B}_{12} \mathrm{Ta}_{70} \mathrm{O}_{193}$ \\
\hline $43: 8$ & 43 & & 4 & 1 & $\mathrm{~B}_{16} \mathrm{Ta}_{86} \mathrm{O}_{239}$ \\
\hline $4: 1$ & 8 & & 1 & & $\mathrm{~B}_{4} \mathrm{Ta}_{16} \mathrm{O}_{46}$ \\
\hline $\mathrm{Ta}_{2} \mathrm{O}_{5}: \mathrm{Al}_{2} \mathrm{O}_{3}$ & & $\left(\mathrm{Ta}_{24} \mathrm{Al}_{2} \mathrm{O}_{63}\right)$ & $\left(\mathrm{Ta}_{15} \mathrm{AlO}_{39}\right)$ & $\left(\mathrm{Ta}_{22} \mathrm{O}_{55}\right)$ & \\
\hline $81: 1$ & 41 & & 1 & 3 & $\mathrm{Ta}_{81} \mathrm{AlO}_{204}$ \\
\hline $59: 1$ & 30 & & 1 & 2 & $\mathrm{Ta}_{59} \mathrm{AlO}_{149}$ \\
\hline $37: 1$ & $\begin{array}{l}30 \\
19\end{array}$ & & 1 & 1 & $\mathrm{Ta}_{37} \mathrm{AlO}_{94}$ \\
\hline $26: 1$ & 27 & & 2 & 1 & $\mathrm{Ta}_{52} \mathrm{Al}_{2} \mathrm{O}_{133}$ \\
\hline $67: 3$ & 35 & & 3 & 1 & $\mathrm{Ta}_{67} \mathrm{Al}_{3} \mathrm{O}_{172}$ \\
\hline $41: 2$ & 43 & & 4 & 1 & $\mathrm{Ta}_{82} \mathrm{Al}_{4} \mathrm{O}_{211}$ \\
\hline $15: 1$ & $\begin{array}{r}70 \\
8\end{array}$ & & 1 & & $\mathrm{Ta}_{15} \mathrm{AlO}_{39}$ \\
\hline $42: 3$ & 45 & $\dddot{m}$ & 4 & & $\mathrm{Ta}_{84} \mathrm{Al}_{6} \mathrm{O}_{219}$ \\
\hline $69: 5$ & 37 & 1 & 3 & & $\mathrm{Ta}_{69} \mathrm{Al}_{5} \mathrm{O}_{180}$ \\
\hline $27: 2$ & 29 & 1 & 2 & & $\mathrm{Ta}_{54} \mathrm{Al}_{4} \mathrm{O}_{141}$ \\
\hline
\end{tabular}

$m=$ Multiplicity of the $b$ axis.

$m=$ The phase with $m=13$ is really $(m=5)+(m=8)$, therefore $x=2$ so in order to find the real $k$ index of the " $\mathrm{C}$ "-line for the $\mathrm{Ta}_{2} \mathrm{O}_{5}$ - $\mathrm{WO}_{3}$ phases one must add $2 x_{1}+x_{2}+x_{3}$ to find the value of $x$ in the equation $k=(m-x)\left[k=m-\left(2 x_{1}+x_{2}+x_{3}\right)\right]$.

TABle 2b. Postulated compositions of phases in the systems involving $\mathrm{Ta}_{2} \mathrm{O}_{5}$ and oxides of other small cations

\begin{tabular}{|c|c|c|c|c|c|}
\hline $\begin{array}{c}\text { System } \\
\text { and } \\
\text { mol ratio }\end{array}$ & $m^{a}$ & $\begin{array}{c}x_{3}{ }^{b} \\
(m=11)\end{array}$ & $\begin{array}{c}x_{4} \\
(m=14)\end{array}$ & $\begin{array}{c}x_{5} \\
(m=17)\end{array}$ & $\begin{array}{c}\text { Formula } \\
\text { per } \\
\text { unit cell }\end{array}$ \\
\hline $\begin{array}{c}\mathrm{Ta}_{2} \mathrm{O}_{5} \mathrm{ZrO}_{2} \\
49: 2 \\
19: 1 \\
27: 2 \\
59: 6\end{array}$ & $\begin{array}{l}25 \\
39 \\
14 \\
31\end{array}$ & $\begin{array}{c}\left(\mathrm{Ta}_{22} \mathrm{O}_{55}\right) \\
1 \\
1 \\
\ldots \ldots \ldots \ldots \ldots\end{array}$ & $\left(\begin{array}{c}\left.\mathrm{Ta}_{27} \mathrm{ZrO}_{69.5}\right) \\
1 \\
2 \\
1 \\
1\end{array}\right.$ & $\begin{array}{c}\left(\mathrm{Ta}_{32} \mathrm{Zr}_{2} \mathrm{O}_{84}\right) \\
\ldots \ldots \ldots \ldots \ldots \ldots \\
\ldots \ldots \ldots \ldots \ldots \ldots \\
\ldots \ldots \ldots \ldots \ldots \ldots \\
1\end{array}$ & $\cdot \begin{array}{l}\mathrm{Ta}_{49} \mathrm{ZrO}_{124.5} \\
\mathrm{Ta}_{76} \mathrm{Zr}_{2} \mathrm{O}_{194} \\
\mathrm{Ta}_{27} \mathrm{ZrO}_{69.5} \\
\mathrm{Ta}_{59} \mathrm{Zr}_{3} \mathrm{O}_{153.5}\end{array}$ \\
\hline
\end{tabular}

a $\quad m=$ Multiplicity of the $b$ axis.

$b$ To find the value of $x$ in the equation $k=(m-x)$ expand into $k=m-\left(x_{3}+x_{4}+x_{5}\right)$. multiplicity equal to, or less than, 50 are shown diagrammatically on the posiulated diagrams (fig. 1-3). Several larger values are shown in the system $\mathrm{Ta}_{2} \mathrm{O}_{5^{-}}$. $\mathrm{TiO}_{2}$ for illustrative purposes. It has now been found that the compound $7: 1$, originally described in the $\mathrm{Ta}_{2} \mathrm{O}_{5}-\mathrm{TiO}_{2}$ system [2] has a multiplicity of 30 . However, the compound originally described as occurring around $2 \mathrm{~mol}$ percent $\mathrm{Ta}_{2} \mathrm{O}_{5}$ has been found to be a manifestation of equilibrium obtained in the $\mathrm{Ta}_{2} \mathrm{O}_{5}$ by the impurities added. This phase has a multiplicity of exactly 11 , which can not be achieved by pure $\mathrm{Ta}_{2} \mathrm{O}_{5}$ at the same temperatures.

It can be seen from table 2a that compositions having equivalent multiplicities in different systems have different cation/anion ratios. Each system has to be calculated on the basis of a different formula. In table $2 \mathrm{a}$ the formula $k=(m-x)$ is expanded into

$$
k=m-\left(2 x_{1}+x_{2}+x_{3}\right)
$$

where $x_{1}, x_{2}$, and $x_{3}$ are the number of $(3 n+5)$ phases in the compositions with multiplicities of 13,8 , and 11 respectively. The only two systems which are alike are $\mathrm{SiO}_{2}$ and $\mathrm{GeO}_{2}$. The composition of the end member $\mathrm{Ta}_{2} \mathrm{O}_{5}$, of course, is the same in each case $11 \mathrm{Ta}_{2} \mathrm{O}_{5}$ $\left(\mathrm{Ta}_{22} \mathrm{O}_{55}\right)$. Theoretically this structure might possibly accommodate three more oxygen ions [7,8]. For a phase with $m=8$ the ideal composition is $\mathrm{Me}_{16} \mathrm{O}_{42}$. In the $\mathrm{Ta}_{2} \mathrm{O}_{5}-\mathrm{WO}_{3}$ system this phase has been found to contain only 40.5 oxygen atoms per 8 subcells and has a composition of $\mathrm{Ta}_{15} \mathrm{WO}_{40.5}$. The phase with $m=13 \mathrm{hav}$ ing an ideal composition of $\mathrm{Me}_{26} \mathrm{O}_{68}$ has been found to have only 67 oxygen atoms and occurs at the composition $\mathrm{Ta}_{22} \mathrm{~W}_{4} \mathrm{O}_{67}[7,8]$. All other multiplicities in this system can be calculated on the basis of these observations. In the $\mathrm{Ta}_{2} \mathrm{O}_{5}-\mathrm{Al}_{2} \mathrm{O}_{3}$ system the phase with $m=8$ occurs at the $15: 1$ ratio and has the composition $\mathrm{Ta}_{15} \mathrm{AlO}_{39}$. Again, all other multiplicities have been calculated on this basis, also assuming the hypothetical phase with $m=13$ (not actually observed in this system) having only 63 oxygens. In the $\mathrm{Ta}_{2} \mathrm{O}_{5}-\mathrm{TiO}_{2}$ system however, the $m=30$ phase has been found at the 7:1 ratio and the hypothetical $m=8$ phase (not found) could therefore have only 38 oxygens as compared to 39 in $\mathrm{Ta}_{2} \mathrm{O}_{5}-\mathrm{Al}_{2} \mathrm{O}_{3}, 40.5$ in $\mathrm{Ta}_{2} \mathrm{O}_{5}-\mathrm{WO}_{3}$ and 42 in the ideal structure. The larger $\mathrm{Zr}^{+4}$ ion causes the $\mathrm{Ta}_{2} \mathrm{O}_{5}-\mathrm{ZrO}_{2}$ system to exhibit multiplicities in opposite direction from all the other systems. The data seem to indicate that the phase with $m=14$ occurs at $\mathrm{Ta}_{27} \mathrm{ZrO}_{69.5}$ as compared to the ideal value of $\mathrm{Me}_{28} \mathrm{O}_{74}$ and compositions of the various phases have been calculated on this basis.

For the other systems, it has been concluded from the limited data that the addition ion enters into tetrahedral interstitual positions with one extra oxygen ion lying above each tetrahedral ion. The $\mathrm{SiO}_{2}$ and $\mathrm{GeO}_{2}$ systems have been calculated assuming that the hypothetical phase with $m=8$ (not observed in either system) has the composition $\mathrm{Me}_{2}^{+4} \mathrm{O}_{2} \mathrm{Ta}_{16} \mathrm{O}_{42}$

$$
\left(\mathrm{Me}_{2} \mathrm{Ta}_{16} \mathrm{O}_{44}=8 \mathrm{Ta}_{2} \mathrm{O}_{5}: 2 \mathrm{MeO}_{2}\right) \text {. }
$$

However, the $\mathrm{Ta}_{2} \mathrm{O}_{5}-\mathrm{B}_{2} \mathrm{O}_{3}$ system seems to contain 
twice as many tetrahedral ions as are found in the $\mathrm{SiO}_{2}$ and $\mathrm{GeO}_{2}$ systems. The compositions have, therefore, been calculated on the basis of a formula for the hypothetical $m=8$ phase (not found) of $\mathrm{B}_{4} \mathrm{O}_{4} \mathrm{Ta}_{16} \mathrm{O}_{42}$ $\left(\mathrm{B}_{4} \mathrm{Ta}_{16} \mathrm{O}_{46}=8 \mathrm{Ta}_{2} \mathrm{O}_{5}: 2 \mathrm{~B}_{2} \mathrm{O}_{3}\right)$. Due to the extreme volatility of $\mathrm{MoO}_{3}$ at high temperatures as well as its tendency to reduce at these temperatures, no statement can be made as to the phases which might form in these systems on the basis of the reported experiments (table 1).

It should be noticed (table 1) that the " $\mathrm{C}$ "-line moves the same way for a $\mathrm{W}^{+6}$ cation as it does for an $\mathrm{Al}^{+3}$ cation or for any of the small ions regardless of valence. It is apparent that the position of the " $\mathrm{C}$ "-line is more dependent upon the amount and size of the cation than it is upon the valance. This leads to the conclusion that the size of the unit cell superstructure is more dependent upon the number of smaller cations which are included in the composition than upon the total number of oxygen ions. Before a final answer can be offered for this problem, single crystal structure determinations must be made for some of these compositions.
The system $\mathrm{Ta}_{2} \mathrm{O}_{5}-\mathrm{WO}_{3}$ was, therefore, selected for further study in order to determine the number of phases of the low- $\mathrm{Ta}_{2} \mathrm{O}_{5}$ type which can be formed and to grow small single crystals for structural analyses. The results of this study will be reported elsewhere [9].

\section{References}

[1] Reisman, A., Holtzberg, F., Berkenblit, M., and Berry, M., J. Am. Chem. Soc. 78, 4514 (1956).

[2] Waring, J. L., and Roth, R. S., Nat. Bur. Stand. (U.S.), 72A (Phys. and Chem.) No. 2, 175-186 (Mar.-Apr. 1968).

[3] Jahnberg, L., and Andersson, S., Acta Chem. Scand. 21, 615 (1967).

[4] Levin, E. M., and Roth, R. S., Nat. Bur. Stand. (U.S.), 68A (Phys. and Chem.) No. 2, 197-206 (Mar--Apr. 1964).

[5] Roth, R. S., Waring, J. L., and Brower, W. S., Nat. Bur. Stand. (U.S.), 74A (Phys. and Chem.) No. 4, (July-Aug. 1970).

[6] Moser, R., Schweiz. Mineral. Petrog. Mitt. 45, 35 (1965).

[7] Roth, R. S., and Stephenson, N. C., Chemistry of Extended Defects in Non-Metallic Solids, 167-182 (North Holland Publishing Co., Amsterdam 1970).

[8] Stephenson, N. C., and Roth, R. S., Acta Cryst. (in press).

[9] Roth, R. S., Waring, J. L., Parker, H. S. J. Solid State Chem. (to be published),

(Paper 74,A4-614) 